\title{
The Relationship between Audit Committee Effectiveness and Audit Fees: Insights from Indonesia
}

\author{
Indira JANUARTI ${ }^{1}$, Darsono DARSONO ${ }^{2}$, Anis CHARIRI ${ }^{3}$ \\ Received: May 18, 2020 Revised: May 24, 2020 Accepted: June 07, 2020
}

\begin{abstract}
This study examines the relationship between the effectiveness of an audit committee and the amount of audit fees. The sample consists of 130 manufacturing companies listed on the Indonesia Stock Exchange (IDX) in 2016-2017. Data are obtained from the IDX and company's annual reports. The effectiveness of an audit committee is measured by independent audit committee size, frequency of audit committee meetings, and expertise of the audit committee. Results show first that the size of the independent audit committee has a positive effect on audit fees. This finding suggests that an increase in the number of independent audit committee members produces a higher quality of reporting, and so they tend to choose a reputable public accountant. Second, the frequency of its meetings has positive effects on audit fees. It suggests that the more effective the supervision of the committee to improve audit quality, the higher the audit fees to be paid. However, this study fails to provide evidence that the expertise of the audit committee affects audit fees. The result of this study suggests that the audit committee tends to adopt the demand approach based on the reputation of the public accounting firm accountant firm in determining the amount of audit fees.
\end{abstract}

Keywords: Audit Fee, Audit Committee, Demand-Supply Approach, Indonesia

JEL Classification Code: M20, M40, M41, M42, M48

\section{Introduction}

The Financial Services Authority Regulation/Peraturan Otoritas Jasa Keuangan (POJK) No. 13/POJK.03/2017 on the "Use of Public Accountant Services and Public Accounting Firms/Kantor Akuntan Publik (KAP) in Financial Services Activities" states that companies on the stock exchange

${ }^{1}$ First Author and Corresponding Author. Accounting Department, Faculty of Economics and Business, Universitas Diponegoro, Semarang, Indonesia [Postal Address: JI. Prof. Sudarto No.13, Tembalang, Kec. Tembalang, Kota Semarang, Jawa Tengah 50275, Indonesia] Email: indirajanuarti@lecturer.undip.ac.id

${ }^{2}$ Accounting Department, Faculty of Economics and Business, Universitas Diponegoro, Semarang, Indonesia. Email: darsono@lecturer.undip.ac.id

${ }^{3}$ Accounting Department, Faculty of Economics and Business, Universitas Diponegoro, Semarang, Indonesia. Email: anischariri@lecturer.undip.ac.id

(c) Copyright: The Author(s)

This is an Open Access article distributed under the terms of the Creative Commons Attribution Non-Commercial License (http://Creativecommons.org/licenses/by-nc/4.0/) which permits unrestricted noncommercial use, distribution, and reproduction in any medium, provided the original work is properly cited. must disclose their audited financial statements (Otoritas Jasa Keuangan, 2017). Thus, companies have to pay audit fees to external auditors for services that have been provided by public accountants. The amount of audit fees is regulated by the Indonesian Institute of Certified Public Accountants (IAPI) Regulation No. 2/2016 (IAPI, 2016) and is based on the agreement between the auditee and the auditor. Investigating the amount of audit fees is an interesting topic because the transparency of standalone audit fees provided by Indonesian listed companies in their financial statements remains low. Therefore, research on the transparency of audit fees needs to be investigated (Januarti \& Wiryaningrum, 2019; Sinaga \& Rachmawati, 2018). The Sarbanes-Oxley Act also regulates that audit and non-audit services may not be carried out in the same year by public accountant firms. The demand-supply perspective can be used to determine the amount of audit fees ( $\mathrm{Wu}, 2012$; Yasin \& Nelson, 2012). The demand side displays high audit fees when the audit committee wants financial statements to have high value added, such that the committee chooses a reputable public accountant firm. Meanwhile, the supply side shows that when corporate governance is good, the risk faced by auditors is reduced; therefore, audit fees are low. 
Previous studies suggested that the implementation of effective corporate governance may reduce audit fees (Boo \& Sharma, 2008; Majeed et al., 2020). In Indonesia, the existence of an audit committee as an element of corporate governance is regulated in POJK No. 55/POJK.04/2015. The regulation states that the role of the audit committee is directly related to external auditors (Otoritas Jasa Keuangan, 2015). This study used audit committee effectiveness as a proxy for corporate governance implementation because the role of the audit committee is an important function in overseeing financial reporting (Bédard \& Gendron, 2010; Li et al., 2012; Lisic et al., 2016). For example, the audit committee plays an active role in reviewing financial statements (Haji, 2015; Khanifah et al., 2020). Felo et al. (2003) argued that an independent audit committee can prevent a company from committing accounting irregularities, and the size and expertise of the audit committee can improve the quality of published financial information. Some studies suggested that the effectiveness of audit committees in monitoring corporate reporting policies is influenced by several factors, such as composition, size, and qualifications, as well as the activities carried out by the audit committee (Abbott et al., 2004; Carcello \& Neal, 2003; Ha \& Nguyen, 2020; Klein, 2002). In addition, a related study on the Johannesburg Stock Exchange indicated that audit committee characteristics, especially their expertise and frequency of meetings, significantly influence the integrated reporting of companies listed on a stock exchange (Chariri \& Januarti, 2017).

Several studies have investigated the relationship among existing audit committee attributes. Companies that have a large number of audit committee members, hold meetings often, and have many accounting members (Yatim et al., 2006) found that the more financial or business expertise an audit committee has, the lower the audit fees to be paid. Prior studies also showed that the number of meetings conducted by the audit committee can reduce problems in financial reporting, and therefore the audit fees paid by the firm will be lower (Farooq et al., 2018). Different conclusions were presented by other studies, such as Vafeas and Waegelein (2007), who reported an insignificant relationship between frequency of meetings and audit fees. On the other hand, Yasin and Nelson (2012) and Goodwin-Stewart and Kent (2006) found a positive relationship between these two attributes. An educational background is necessary to manage a company's business (Yasin \& Nelson, 2012). An audit committee that has a large number of members with financial or accounting expertise provides good supervision and wants to increase the value of the company by choosing a reputable public accountant firm, and thus audit fees to be paid are high (Yasin \& Nelson, 2012). However, Goodwin-Stewart and Kent (2006) provided evidence that the expertise of the audit committee has no positive effect on audit fees.
Based on the explanation above, the effectiveness of an audit committee and the amount of audit fees have a mixed relationship. Therefore, the research question to be answered is whether audit committee attributes influence the amount of audit fees. This study is expected to contribute to accounting and auditing literature by adopting demandsupply approaches to provide evidence regarding the factors that influence the amount of audit fees. This study also provides evidence about the relationship from the perspective of an emerging country, because most prior studies were conducted in developed countries. Through its findings, this study can provide decision makers insights into regulations regarding the effectiveness of audit committees.

\section{Literature Review and Hypothesis Development}

\subsection{Agency Theory}

Agency theory explains the working relationship between principal and agent. The principal delegates their authority to the agent (management) so the agent can make a decision (Jensen \& Meckling, 1976). Agents run the company's business with various risks that can occur. As a form of accountability, agents make financial reports every year. These statements are monitored both by internal parties (in this case the audit committee) and independent external parties (auditor). Audit committees play important roles in monitoring company policies (Trotman \& Trotman, 2015). Financial statement audit is a form of supervision to prevent agency problems from arising. Audit fees are monitoring costs that are necessarily incurred by the agent (Jensen \& Meckling, 1976). As an external auditor, a public accountant is an independent third party believed to be capable of providing confidence about the fairness of the financial statements presented by the management (agent). The characteristics of audit committees consist of their expertise, frequency of meetings, and independence. Expertise in accounting/finance allows audit committee members to understand the auditing process and resolve disagreements between management and external auditors (Mangena \& Tauringana, 2008). Effective monitoring may increase when audit committee members meet regularly and frequently (Lisic et al., 2016). Independent audit committees can ensure a higher quality of financial reporting (Ebrahim \& Fattah, 2015) and is regarded as a cornerstone of audit committee effectiveness (Psaros \& Seamer, 2004).

\subsection{Audit Committee Size and Audit Fees}

The audit committee is formed by a board of commissioners. According to agency theory, internal control to reduce agency costs is carried out by the audit committee. 
POJK Number 55/POJK.04/2015 states that the existence of an audit committee is mandatory, which means that every company going public is required to have an audit committee. An audit committee is a committee that is responsible to the board of commissioners and assists the board in overseeing internal and external audit functions (Otoritas Jasa Keuangan, 2015). Al-Najjar (2011) and Carcello and Neal (2003) found that independent audit committee members force management to have more transparency and accountability. Such members can ensure a higher quality of financial reporting (Ebrahim \& Fattah, 2015) as they are more autonomous and free from any vested interests (Hamid et al., 2015).

The role of audit committees in monitoring company policies cannot be separated from the independence of its members (Chariri \& Januarti, 2017). A large number of independent audit committee members indicate adequate resources, such that the supervisory function can run more effectively. In the supply side, when supervision is effective, the audit fees paid to the public accounting firm are low because the risk borne by the auditor is small. Hassan and Naser (2013) and Yatim et al. (2006) provided evidence that the audit committee has a negative effect on audit fees. By contrast, the demand side explains that when the number of independent committee members is large, the desire for higher quality financial reports increases. Therefore, the members tend to choose a reputable public accountant even though the audit fees to be paid are high. Yasin and Nelson (2012) provided empirical evidence that the existence of the audit committee has a positive effect on the amount of audit fees. Based on the explanation above, the determination of audit fees can be high (positive) or low (negative) depending on the approach used.

Hypothesis 1: Audit committee size has a positive (negative) effect on audit fees.

\subsection{Audit Committee Meetings and Audit Fees}

According to the supply side, the audit committee that often holds meetings will carry out supervisory duties well; therefore, the audit risk is less $(\mathrm{Wu}, 2012)$ and problems in financial reporting are reduced (Yatim et al., 2006). Meetings conducted by the audit committee are one way of monitoring costs to reduce agency problems. A high frequency of meetings may lead to a low risk of quality financial reports, and therefore the audit fees will be low (Farooq et al., 2018; Yatim et al., 2006). The more audit committees hold meetings, the more effective their role will be in monitoring the preparation and presentation of integrated reports and, consequently, the more items will be disclosed in integrated reports. Audit committee meetings are an effective medium of communication among audit committee members to share their views and expertise with regard to integrated reporting
(Chariri et al., 2017). Audit committees should hold more regular and scheduled meetings. The explanation of the supply approach therefore suggests that the frequency of audit committee meetings has a negative effect on audit fees.

The active involvement of audit committee members in regularly scheduled meetings enables them to discuss any issues related to company activities. Meetings enable audit committees to oversee accounting records and the quality of internal control more effectively (Hoque et al., 2013; Lisic et al., 2016). Moreover, the increasing frequency of audit committee meetings leads to improvements in accounting information and audit quality (Song \& Windram, 2004). Audit committees positively influence financial reporting quality (Zhang et al., 2007). The demand-side approach explains that, when the audit committee conducts many meetings, it demonstrates that it wants good quality financial reports. The audit committee selects a reputable public accountant with the hope that the resulting audited report will increase the value of the company. The demand side explains that the frequency of audit committee meetings has a positive effect on audit fees. Yasin and Nelson (2012) provided evidence that the frequency of audit committee meetings has a positive effect on audit fees. Thus, audit costs can be high (positive) or low (negative) depending on the approach used.

Hypothesis 2: The frequency of audit committee meetings has a positive (negative) effect on audit fees

\subsection{Audit Committee Expertise and Audit Fees}

Expertise in accounting/finance is seen as crucial to audit committee members (Abernathy et al., 2015). Numerous studies showed that audit committee effectiveness is determined by the knowledge and expertise in finance/ accounting of its members (Abernathy et al., 2013). Audit committee members with accounting/financial expertise tend to respond quickly to changes in the business environment and innovation (Badolato et al., 2014). Audit committees with members who are expert in accounting/finance will increase the number of items disclosed in integrated reports (Chariri \& Januarti, 2017). POJK No.55/POJK.04/2015 explained that audit committee members must have adequate knowledge and ability in business and finance and be able to understand the contents of financial statements. One of the members must have an educational background in accounting or finance (Otoritas Jasa Keuangan, 2015). Audit committee expertise can enhance the capabilities of audit committee members in monitoring the financial reporting process, especially the publication of integrated reports (Chariri \& Januarti, 2017). Agency theory claims that audit committee members must have expertise in accounting/ finance to decrease information asymmetry and align agent interests to principal ones (Jensen \& Meckling, 1976). 
The supply side explains that members who have accounting and financial expertise can increase the effectiveness of the audit committee's performance and reduce agency problems. Such expertise allows audit committee members to understand the auditing process and resolve disagreements between management and external auditors (Li et al., 2012). The expertise of the audit committee is expected to reduce the testing conducted by the auditor so that audit fees are reduced. The demand side explains that audit committee members who have educational backgrounds in accounting and business can understand financial statements better. With these conditions, the committee members prefer a quality audit and thus choose a reputable public accountant. A consequence of selecting a reputable public accountant is high audit fees. Yatim et al. (2006) and Vafeas and Waegelein (2007) argued that the expertise of the audit committee has a positive effect on audit fees.

Hypothesis 3: Audit committee expertise has a positive (negative) effect on audit fees

\section{Research Methods}

\subsection{Sample}

The population in this study comprises manufacturing companies listed on the Indonesia Stock Exchange (IDX) in 2016-2017. The audited company annual report data are obtained from www.idx.co.id. The sampling criteria in this study are as follows: 1) manufacturing companies listed on the IDX in 2016-2017 and 2) company reports where audit fees are separate from other professional fees. Table 1 shows that 55 companies presented their audit fee information separate from other professional costs in 2016 while 75 companies did so in 2017. Thus, the number of research samples is 130 .

\subsection{Measurement and Analysis of Variables}

Table 2 presents the measurement of variables. This study used multiple linear regression analysis to answer the research question. The statistical regression equation is as follows:

$$
\mathrm{AUFEE}=\mathrm{b}_{0}+\mathrm{b}_{1} \text { ACSIZE }+\mathrm{b}_{2} \text { ACFREQ }+\mathrm{b}_{3} \mathrm{ACEXP}+\mathrm{e}
$$

\section{Results}

\subsection{Descriptive Statistics}

Table 3 shows the descriptive statistics of the variables. The lowest number of independent audit committee members is 2 and the highest is 4 , with a median and mean of 3. This finding is consistent with Article 4 of POJK No.55/ POJK.04/2015, which stated that the minimum number of independent audit committee members is 3 . The least number of meetings conducted by an audit committee in one year is 2 and the most number is 32 , which occurred four times. The average number of 6.4 audit committee meetings is high, given that Article 13 of POJK No.55/POJK.04/2015 only sets a minimum requirement of one meeting at least every three months or four times a year.

For the variable of educational background of the audit committee, the sample has a minimum of 1 and a maximum of 4 members with educational backgrounds in the accounting/ finance fields. The average number of audit committee members with the relevant educational background is 2.9, with a median value of 2 . This average is higher than the minimum requirement of one person in Article 13 of POJK No.55/POJK.04/2015. For the dependent variable, the lowest audit fee is 98,252,000 rupiahs, whereas the highest

Table 1: Sample selection

\begin{tabular}{|l|c|c|c|}
\hline \multicolumn{1}{|c|}{ Criteria } & $\mathbf{2 0 1 6}$ & $\mathbf{2 0 1 7}$ & Total \\
\hline Manufacturing companies listed on the Indonesia Stock Exchange & 147 & 160 & 307 \\
\hline Companies that did not have audit fee information & $(92)$ & $(85)$ & $(177)$ \\
\hline Companies that disclosed external audit fees & 55 & 75 & 130 \\
\hline
\end{tabular}

Table 2: Measurement of variables

\begin{tabular}{|l|l|c|}
\hline \multicolumn{1}{|c|}{ Variable } & \multicolumn{1}{c|}{ Measurement } & Code \\
\hline Audit fees & Logarithm natural (Ln) audit fee & AUFEE \\
\hline Audit committee size & number of independent audit committee members & ACSIZE \\
\hline Audit committee meetings & number of audit committee meetings held in one year & ACFREQ \\
\hline Audit committee expertise & $\begin{array}{l}\text { number of audit committee members who have educational backgrounds } \\
\text { in accounting or finance }\end{array}$ & ACEXP \\
\hline
\end{tabular}


Table 3: Descriptive statistics

\begin{tabular}{|l|c|c|c|c|c|}
\hline \multicolumn{1}{|c|}{ Variables } & Minimum & Maximum & Mean & Median & St Deviation \\
\hline Aufee (000) & 98,250 & $13,422,171$ & $1,191,815$ & 592,500 & $1,975,440$ \\
\hline Ln Aufee & 18.40 & 23.32 & 20.26 & 20.20 & 1.129 \\
\hline ACSIZE & 2 & 4 & 3.03 & 3 & 0.344 \\
\hline ACFRE & 2 & 32 & 6.4 & 4 & 5.279 \\
\hline ACEXP & 1 & 4 & 2.9 & 2 & 0.699 \\
\hline
\end{tabular}

Table 4: Multiple regression results

\begin{tabular}{|l|c|c|c|}
\hline \multicolumn{1}{|c|}{ Variable } & Coefficient & t & p-value \\
\hline Constant & 17.388 & 19.532 & .000 \\
\hline ACSIZE & .981 & 3.425 & $.001^{* * *}$ \\
\hline ACFREQ & .628 & 2.438 & $.053^{*}$ \\
\hline ACEXP & -.125 & -.892 & .374 \\
\hline F test $=35.548, p$-value $=.001 \quad$ Adjusted $R^{2}=.096$ & \\
\hline
\end{tabular}

is $13,422,171,311$ rupiahs. The average audit fee paid by the companies is $1,191,815,967$ rupiahs.

\subsection{Regression Analysis}

Table 4 presents the result of the regression analysis. In the table, the coefficient of the independent audit committee (ACSIZE) variable is 0.981 with a p-value of .001 . Thus, Hypothesis 1 is accepted. Consistent with Hypothesis 1, the frequency of audit committee meetings is accepted at a significance level of $10 \%$. The ACFREQ positive coefficient (.628) has a significance of .053, and so Hypothesis 2 is accepted. However, the relationship between audit committee educational background and audit fees, where the coefficient correlation is -.125 and the significance value is .374 , is rejected.

The above results suggest that the independent audit committee has a positive effect on audit fees. In addition, it indicates that the approach used to determine the amount of audit fees is based on the demand perspective. This perspective means that an increase in the number of independent audit committee members produces a higher quality of reporting, and so they tend to choose a reputable public accountant. This result is consistent with those of Ali et al. (2018) and Goodwin-Stewart and Kent (2006). According to agency theory, a worthy supervision from an independent audit committee may improve the reporting quality, which can decrease the agency problems.

The number of audit committee meetings has a positive effect on audit fees. For this variable, a positive coefficient indicates that the demand perspective is used to determine audit costs. The larger the number of meetings conducted by the audit committee, the more effective the supervision of the committee to improve audit quality, and the higher the audit fees to be paid because a qualified public accountant will be chosen. This positive value can be explained as follows: when the number of audit committee meetings < 4 , the average value of audit fees is 925,200,910 rupiahs, but when the number $>4$, the average value increases to $1,522,786,385$ rupiahs. The results of this study support the findings of Yasin and Nelson (2012) and Goodwin-Stewart and Kent (2006) but are not consistent with the finding of Vafeas and Waegelein (2007).

The educational background of the audit committee does not have a negative effect on audit fees. The negative coefficient indicates that the supply perspective is used to determine audit costs for the educational background variable of the audit committee. An increasing number of audit committee members with educational backgrounds in accounting/finance leads to low audit fees low because of good internal supervision. Hence, the risk of financial reporting problems is small. The negative coefficient value can be explained by the following data: when the educational backgrounds of audit committee members in accounting/ finance $<2$, the audit fees are 1,232,593,518 rupiahs, but when the educational backgrounds $>2$, the audit fees decrease to $1,128,650,743$ rupiahs. Even though the difference in average audit fees after further testing is statistically insignificant, Hypothesis 3 is still rejected. This result is the same as that of Goodwin-Stewart and Kent (2006), who provided evidence that the educational background of the audit committee has no effect on audit fees. This research contradicts Yatim et 
al. (2006) Yatim et al. (2006) and Vafeas and Waegelein (2007), who reported that the audit committee's educational background has a positive effect on audit fees.

\section{Conclusions}

This research concludes that the independent audit committee has a positive effect on audit fees because it encourages management to be more transparent and accountable. The large number of independent audit committee members prefers qualified public accountants to increase company value. The selection of qualified accountants indicates that companies prefer to use the demand approach. Furthermore, the number of meetings held by the audit committee has a positive effect on audit fees. This result can be explained by the fact that a larger number of meetings conducted provide more information to the audit committee, such that it can improve financial reports by using qualified accountants. In determining audit fees, companies tend to use the demand approach by choosing reputable accountants, and so the audit costs are high. However, this research fails to provide evidence that educational background has no effect on audit fees. Audit committee expertise shows a negative coefficient. Thus, for this hypothesis, the company uses a supply approach.

These findings imply that the approach taken to determine audit fees tends to be based on the demand perspective. An effective audit committee in accordance with OJK regulations prioritizes the quality of audit reports. With a good quality audit report, investors will expectedly be more confident in the financial reporting and the company's value will subsequently increase. This study suffers some limitations, such as it only includes a few companies that listed audit fees separately from other professional fees. In addition, the value of adjusted $\mathrm{R}^{2}$ is only $9.6 \%$ so that there are still many other variables that can affect audit fees. Future studies are recommended to consider adding a sample of companies with a longer observation period. Other variables can also be added, such as the qualifications of public accountants and public accounting changes that have not been researched extensively.

\section{References}

Abbott, L. J., Parker, S., \& Peters, G. F. (2004). Audit Committee Characteristics and Restatements. Auditing: Journal of Practice \& Theory, 23(1), 69-86.

Abernathy, J. L., Beyer, B., Masli, A., \& Stefaniak, C. M. (2015). How the Source of Audit Committee Accounting Expertise Influences Financial Reporting Timeliness. Current Issues in Auditing, 9(1), 1-9. doi:10.2308/ciia-51030

Abernathy, J. L., Herrmann, D., Kang, T., \& Krishnan, G. V. (2013). Audit committee financial expertise and properties of analyst earnings forecasts. Advances in Accounting, 29(1), 1-11. doi:10.1016/j.adiac.2012.12.001

Al-Najjar, B. (2011). The Determinants of Audit Committee Independence and Activity: Evidence from the UK. International Journal of Auditing, 15(2), 191-203. doi:10.1111/ j.1099-1123.2011.00429.x

Ali, M. J., Singh, R. K. S., \& Al-Akra, M. (2018). The impact of audit committee effectiveness on audit fees and non-audit service fees. Accounting Research Journal, 31(2), 174-191. doi:10.1108/arj-11-2015-0144

Badolato, P. G., Donelson, D. C., \& Ege, M. (2014). Audit committee financial expertise and earnings management: The role of status. Journal of Accounting and Economics, 58(2-3), 208-230. doi:10.1016/j.jacceco.2014.08.006

Bédard, J., \& Gendron, Y. (2010). Strengthening the Financial Reporting System: Can Audit Committees Deliver? International Journal of Auditing. doi:10.1111/j.10991123.2009.00413.x

Boo, E. F., \& Sharma, D. (2008). The association between corporate governance and audit fees of bank holding companies. Corporate Governance: The international Journal of Business in Society, 8(1), 28-45. doi:10.1108/14720700810853383

Carcello, J. V., \& Neal, T. L. (2003). Audit Committee Independence and Disclosure: choice for financially distressed firms. Corporate Governance: An International Review, 11(4), 289299.

Chariri, A., \& Januarti, I. (2017). Audit Committee Characteristics and Integrated Reporting:Empirical Study of Companies Listed on the Johannesburg Stock Exchange. European Research Studies Journal, XX(4B), 305-318.

Chariri, A., Januarti, I., \& Yuyetta, E. N. A. (2017). Firm Characteristics, Audit Committee, and Environmental Performance: Insights from Indonesian Companies. International Journal of Energy Economics and Policy, 7(6), 19-26.

Ebrahim, A., \& Fattah, T. A. (2015). Corporate governance and initial compliance with IFRS in emerging markets: The case of income tax accounting in Egypt. Journal of International Accounting, Auditing and Taxation, 24, 46-60. doi:10.1016/j. intaccaudtax.2015.02.003

Farooq, M. U., Kazim, I., \& Usman, M. (2018). Corporate Governance and Audit Fees: Evidence from a Developing Country. Pakistan Journal of Commerce and Social Sciences, 12(1), 94-110.

Felo, A. J., Krishnamurthy, S., \& Solieri, S. (2003). Audit Committee Characteristics and the Perceived Quality of Financial Reporting: An Empirical Analysis. SSRN.

Goodwin-Stewart, J., \& Kent, P. (2006). Relation between external audit fees, audit committee characteristics and internal audit. Accounting and Finance, 46(3), 387-404. doi:10.1111/j.1467629X.2006.00174.X

Ha, H. H., \& Nguyen, A. H. (2020). Determinants of Voluntary Audit of Small and Medium Sized Enterprises: Evidence from 
Vietnam. Journal of Asian Finance, Economics and Business, 7(5), 41-50. https://doi.org/10.13106/jafeb.2020.vol7.no5.041

Haji, A. A. (2015). The role of audit committee attributes in intellectual capital disclosures. Managerial Auditing Journal, 30(8/9), 756-784. doi:10.1108/maj-07-2015-1221

Hamid, K. C. A., Othman, S., \& Rahim, M. A. (2015). Independence and Financial Knowledge on Audit Committee with Non-compliance of Financial Disclosure: A Study of Listed Companies Issued with Public Reprimand in Malaysia. Procedia - Social and Behavioral Sciences, 172, 754-761. doi:10.1016/j.sbspro.2015.01.429

Hassan, Y. M., \& Naser, K. (2013). Determinants of Audit Fees: Evidence from an Emerging Economy. International Business Research, 6(8). doi:10.5539/ibr.v6n8p13

Hoque, M. Z., Islam, M. D. R., \& Azam, M. N. (2013). Board Committee Meetings and Firm Financial Performance: An Investigation of Australian Companies. International Review of Finance, 13(4), 503-528. doi:10.1111/irfi.12009

IAPI. (2016). Peraturan Pengurus No. 2/2016 Tentang Penentuan Imbalan Jasa Audit Laporan Keuangan. Retrieved from http:// iapi.or.id/Iapi/detail/120

Januarti, I., \& Wiryaningrum, M. S. (2019). The Effect of Size, Profitability, Risk, Complexity, and Independent Audit Committee on Audit Fee. Jurnal Dinamika, 10(2), 136-145.

Jensen, M. C., \& Meckling, W. H. (1976). Theory of the Firm: Managerial Behavior, Agency Costs and Ownership Structure. Journal of Financial Economics, 3(4), 305-360.

Khanifah, K., Hardiningsih, P., Darmaryantiko, A., Iryantika, I., \& Udin, U. (2020). The Effect of Corporate Governance Disclosure on Banking Performance: Empirical Evidence from Iran, Saudi Arabia and Malaysia. Journal of Asian Finance, Economics and Business, 7(3), 41-51. https://doi.org/10.13106/ jafeb.2020.vol7.no3.41

Klein, A. (2002). Audit committee, board of director characteristics, and earnings management. Journal of Accounting and Economics, 33(3), 375-400.

Li, J., Mangena, M., \& Pike, R. (2012). The effect of audit committee characteristics on intellectual capital disclosure. The British Accounting Review, 44(2), 98-110. doi:10.1016/j. bar.2012.03.003

Lisic, L. L., Neal, T. L., Zhang, I. X., \& Zhang, Y. (2016). CEO Power, Internal Control Quality, and Audit Committee Effectiveness in Substance Versus in Form. Contemporary Accounting Research, 33(3), 1199-1237. doi:10.1111/19113846.12177

Majeed, M. K., Jun, J. C., Zia-Ur-Rehman, M., Mohsin, M., \& Rafiq, M. Z. (2020). The Board Size and Board Composition
Impact on Financial Performance: An Evidence from the Pakistani and Chinese's Listed Banking Sector. Journal of Asian Finance, Economics and Business, 7(4), 81-95. https:// doi.org/10.13106/jafeb.2020.vol7.no4.81

Mangena, M., \& Tauringana, V. (2008). Audit Committees and Voluntary External Auditor Involvement in UK Interim Reporting. International Journal of Auditing, 12(1), 45-63.

Otoritas Jasa Keuangan. (2015). POJK No. 55/POJK.04/2015 Pembentukan dan Pedoman Pelaksanaan Kerja Komite Audit. Jakarta, Pemerintah Indonesia. Retrieved from https://www. ojk.go.id/id/Regulasi/Default.aspx

Otoritas Jasa Keuangan. (2017). POJK No. 03/POJK/2017 Penggunaan Jasa Akuntan Publik dan Kantor Akuntan Publik Dalam Kegiatan Jasa Keuangan. Retrieved from Jakarta: https://www.ojk.go.id/id/Regulasi/Default.aspx

Psaros, J., \& Seamer, M. (2004). Australian audit committees Do they meet best practice guidelines? Australian Accounting Review, 14(3), 77-85.

Sinaga, E. A., \& Rachmawati, S. (2018). Besaran Fee Audit Pada Perusahaan Yang Terdaftar Di Bursa Efek Indonesia. Media Riset Akuntansi, Auditing \& Informasi, 18(1), 19-34.

Song, J., \& Windram, B. (2004). Benchmarking Audit Committee Effectiveness in Financial Reporting. International Journal of Auditing, 8(3), 195-205.

Trotman, A. J., \& Trotman, K. T. (2015). Internal Audit's Role in GHG Emissions and Energy Reporting: Evidence from Audit Committees, Senior Accountants and Internal Auditors. Auditing: Journal of Practice \& Theory, 34(1), 199-230.

Vafeas, N., \& Waegelein, J. F. (2007). The association between audit committees, compensation incentives, and corporate audit fees. Review of Quantitative Finance and Accounting, 28(3), 241-255. doi:10.1007/s11156-006-0012-9

Wu, X. (2012). Corporate governance and audit fees: Evidence from companies listed on the Shanghai Stock Exchange. China Journal of Accounting Research, 5(4), 321-342. doi:10.1016/j. cjar.2012.10.001

Yasin, F. M., \& Nelson, S. P. (2012). Audit Committee and Internal Audit : Implication on Audit Quality. International Journal of Economics, Management and Accounting, 20(2), 187-218.

Yatim, P., Kent, P., \& Clarkson, P. (2006). Governance structures, ethnicity, and audit fees of Malaysian listed firms. Managerial Auditing Journal, 21(7), 757-782. doi:10.1108/02686900610680530

Zhang, Y., Zhou, J., \& Zhou, N. (2007). Audit committee quality, auditor independence, and internal control weaknesses. Journal of Accounting and Public Policy, 26(3), 300-327. doi:10.1016/j. jaccpubpol.2007.03.001 